\title{
Scale-up of PEEK Hollow Fiber Membrane Contactor for Post-combustion $\mathrm{CO}_{2}$ Capture
}

\author{
Shiguang Li, ${ }^{\text {, a }}$ Travis J. Pyrzynski, ${ }^{\text {a }}$ Naomi B. Klinghoffer, ${ }^{\text {a }}$ Timothy Tamale, ${ }^{\text {a }}$ Yongfang Zhong, \\ James L. Aderhold, ${ }^{a}$ S. James Zhou, ${ }^{a}$ Howard S. Meyer, ${ }^{a}$ Yong Ding, ${ }^{b}$ and Benjamin Bikson ${ }^{b}$ \\ ${ }^{a}$ Gas Technology Institute, 1700 S. Mount Prospect Road, Des Plaines, IL 60018, USA \\ ${ }^{\mathrm{b}}$ Air Liquide Advanced Separations, 35A Cabot Road, Woburn, MA 01801, USA
}

December 4, 2016

Revised: January 3, 2017

\begin{abstract}
Poly(ether ether ketone) (PEEK) hollow fiber membrane modules were scaled up from 2 inch diameter and 16 inch long to 4 inch diameter and 58 inch long (a factor of 90 increase in membrane area) for $\mathrm{CO}_{2}$ capture from flue gases using a membrane contactor process, which combines advantageous features of both absorption and membrane processes. Field tests of a 4-inch-diameter module with activated methyldiethanolamine (aMDEA) solvent demonstrated greater than $90 \% \mathrm{CO}_{2}$ removal. The mass transfer coefficient in the absorption step was $1.2(\mathrm{sec})^{-1}$, which is over an order of magnitude greater than that of conventional column contactors. The membrane module was further scaled up from 4 inch to 8 inch diameter (a factor of 3 increase in membrane area). Singlegas permeation measurements indicated that 8 -inch modules have an intrinsic $\mathrm{CO}_{2}$ permeance as high as 2,150-2,670 GPU. One 8-inch-diameter module was tested in membrane contactor mode for $\mathrm{CO}_{2}$ capture using a simulated flue gas. Carbon dioxide removal rate of $91.3 \%$ was achieved with a mass transfer coefficient of $1.5(\mathrm{sec})^{-1}$. Parametric tests indicated $\mathrm{CO}_{2}$ flux and capture rate increased with increasing feed pressure, solvent flow velocity and solvent temperature. PEEK hollow fiber membrane contactor is effective in capturing $\mathrm{CO}_{2}$ from low $\mathrm{CO}_{2}$-concentration feeds, showing its high potential for natural gas flue gas $\mathrm{CO}_{2}$ capture.
\end{abstract}

Keywords: gas separation; carbon capture; membrane contactor; $\mathrm{CO}_{2}$ capture; polymer membrane; hollow fiber membrane; polyether ether ketone membrane

\footnotetext{
* Corresponding author: Shiguang.Li@gastechnology.org; 847-544-3478 (phone); 847-544-3470 (fax)
} 


\section{Introduction}

The greatest concern to climate change is the emission of greenhouse gases, especially $\mathrm{CO}_{2}$ from fossil-fuel power plants. The amount of $\mathrm{CO}_{2}$ attributed to the U.S. electric power sector is expected to increase by $11 \%$ from 2012 to 2040 , although electric power generation from noncarbon sources (such as nuclear and renewable fuels) is projected to increase during this period [1]. Therefore, to address concerns about global climate change, $\mathrm{CO}_{2}$ capture and storage is one of many approaches that is critical to significantly reducing domestic and global $\mathrm{CO}_{2}$ emissions.

The US Department of Energy (DOE) has a goal of achieving 90\% capture rate in existing plants with $95 \% \mathrm{CO}_{2}$ purity at a cost of $\$ 40 /$ tonne of $\mathrm{CO}_{2}$ captured by 2025 [2]. To achieve this goal by any technological means is very difficult, because flue gas is hot, near atmospheric pressure, high in volume, and often contaminated with other impurities $\left(\mathrm{O}_{2}, \mathrm{SO}_{\mathrm{x}}, \mathrm{NO}_{\mathrm{x}}\right.$, and ash). Amine absorption is the current industry and DOE benchmark technology for capture of $\mathrm{CO}_{2}$ from power plant flue gas. Residual oxygen in the flue gas is especially troublesome for conventional amine plants because of oxidative degradation of the amine. In addition, the heat duty of the stripper places a substantial burden on the steam supply. It is estimated that for every pound of $\mathrm{CO}_{2}$ captured, 2 to 3 pounds of steam is required [3,4]. DOE/NETL systems analysis studies estimated that using aqueous monoethanolamine absorption process to capture $90 \%$ of the $\mathrm{CO}_{2}$ from flue gas in existing plants will result in $\mathrm{CO}_{2}$ capture cost of $\$ 56 /$ tonne (DOE Case 12) at the plant gate [5], which is above the 2025 DOE NETL Carbon Capture Program post-combustion capture cost goal (\$40/tonne of $\mathrm{CO}_{2}$ captured). These factors result in enormous amine circulation rates, large equipment, and large energy requirements. Therefore, it is important to develop new advanced $\mathrm{CO}_{2}$ capture technologies in order to maintain the cost-effectiveness of U.S. coal-fired power generation.

Through analysis and feasibility studies, Favre [6] reported that gas separation membranes are a technically and economically viable option for post-combustion $\mathrm{CO}_{2}$ capture. Membranes are compact and can be retrofitted onto the tail end of a power-plant flue gas stream without complicated integration schemes. Conventional gas separation membrane process operates by a solution/diffusion mechanism, and the separation driving force is provided by the partial pressure difference of each component across the membrane. This process requires either flue gas compression, permeate sweep, application of permeate side vacuum, or a combination of these steps to provide the separation driving force required. Elaborate process design and optimization become prerequisite for conventional membrane processes in $\mathrm{CO}_{2}$ capture from flue gases [7]. 
The main limitation of conventional membrane processes is the process pressure ratio (feed gas pressure/permeate gas pressure) limitation [8]. In practical gas separation applications, the pressure ratio across the membrane is usually between 5 and 15 [9]. When the membrane separation process is pressure ratio limited, the product $\mathrm{CO}_{2}$ concentration will be limited even when the membrane selectivity is much larger than the pressure ratio. Thus, multiple membrane stages are required to generate greater than $95 \%$ pure $\mathrm{CO}_{2}$ product (DOE's target) from flue gases using the conventional membrane process.

Membrane contactor process (also known as hybrid membrane/absorption process) combines advantageous features of both absorption and membrane processes to provide a cost-effective solution for $\mathrm{CO}_{2}$ capture from flue gases. Hollow fiber membrane contactors for $\mathrm{CO}_{2}$ capture, especially the absorption process, have been reported [10-14]. In this process, $\mathrm{CO}_{2}$-containing gas passes through small-diameter membrane tubes (hollow fibers with porous walls) while a $\mathrm{CO}_{2}$ selective solvent (typically an amine solution) flows on the shell side of the membrane. $\mathrm{CO}_{2}$ permeates through the membrane and is absorbed in the solvent. The $\mathrm{CO}_{2}$ rich solvent is regenerated and sent back to the membrane absorber.

The specific surface area per volume for hollow fiber membrane contactors can be as high as $\sim 1,000-9,000 \mathrm{~m}^{2} / \mathrm{m}^{3}$, which is up to two orders of magnitude greater than conventional contactors (free dispersion columns: $\sim 3.0-35 \mathrm{~m}^{2} / \mathrm{m}^{3}$, packed and tray columns: $30-300 \mathrm{~m}^{2} / \mathrm{m}^{3}$, mechanically agitated columns: $\left.\sim 160-500 \mathrm{~m}^{2} / \mathrm{m}^{3}\right)[15,16]$. Thus, the use of a membrane contactor instead of a conventional amine scrubber leads to a much smaller space requirement. This technology is well suited for new and existing pulverized coal-fired power plants due to the reduced footprint requirement and a much lower visual impact as well as providing more options for placement in the confines of existing plants.

In the hybrid membrane/absorption process, the permeate side partial pressure of $\mathrm{CO}_{2}$ can be considered close to zero due to the chemical reaction of $\mathrm{CO}_{2}$ with the absorption solvent, and thus overcomes the pressure ratio problem encountered by the conventional gas membrane process. Feed compression or permeate vacuum is not required to create the separation driving force for gas molecules to be transported through the membrane. The process selectivity for the hybrid membrane/absorption process is determined by the chemical affinity of the absorption solvent to $\mathrm{CO}_{2}$. Therefore, high purity $\mathrm{CO}_{2}$ product can be realized in a single stage.

In our previous study [17], the feasibility of utilizing PEEK membrane based hollow fiber contactor in combination with chemical solvents to separate and capture $\mathrm{CO}_{2}$ from simulated flue 
gases with high efficiency (at least 90\% removal) has been successfully established via testing of 2inch-diameter modules. Advanced hindered amines and promoted carbonate solvent have been used to minimize solvent degradation and lower regeneration energy requirements. Greater than $90 \% \mathrm{CO}_{2}$ capture with greater than $95 \% \mathrm{CO}_{2}$ purity has been achieved in one stage with activated methyldiethanolamine (aMDEA) solvent. The measured volumetric mass transfer coefficient for the 2-inch-diameter module was as high as $1.7(\mathrm{sec})^{-1}$, which is more than 20 times greater than the mass transfer coefficient of a packed column. The lab tests also indicated that the $\mathrm{CO}_{2}$ capture performance was stable and not affected by flue gas contaminants, including $\mathrm{O}_{2}, \mathrm{NO}_{2}$, and $\mathrm{SO}_{2}$, with aMDEA solvent. The PEEK hollow fiber membrane contactor provides a unique platform to maximize the benefits of new and advanced solvents including those currently supported the DOE,

In the current study, the PEEK membrane modules were scaled up from 2 inch diameter and 16 inch long to 4 inch diameter and 58 inch long (a factor of 90 increase in membrane area) for field testing, then further scaled to commercial-sized 8-inch diameter (another factor of 3 increase in membrane area). High $\mathrm{CO}_{2}$ capture performances were observed for these modules, indicting scalability of the PEEK hollow fiber membrane contactor process.

\section{Experimental Methods}

\subsection{Hollow Fiber Membrane Fabrication and Surface Modification}

The hollow fiber membranes are manufactured from the best in class commercial engineered plastic, PEEK. Porous PEEK hollow fibers used in preparation of super-hydrophobic membranes were manufactured by a high temperature melt extrusion process. In this process, a mixture containing PEEK and PEI (polyether imide), was melt extruded to form a hollow fiber, which was then cooled in air and sent to reagent bath, where PEI was removed. The resulting product was porous PEEK fiber. The details of the process were described previously [18].

The super-hydrophobicity of the porous PEEK membrane was generated by surface modification with a functional perfluoro oligomer. Prior to grafting with the perfluoro oligomer the surface of the porous PEEK was functionalized with -OH groups by reacting ketone groups in the PEEK polymer backbone with monoethanolamine. The functionalized porous PEEK was prepared in a single step Reactive Porogen Removal process during porous PEEK fiber preparation according to US Patent 7,176,273 [19].

\subsection{Membrane Module Fabrication and Characterization}


Module design and construction have significant impacts on the overall gas mass transfer coefficient by minimizing liquid side resistance and maximizing the driving force. The following key design elements and development work have been carried out:

1) Four-port counter-current flow design, enabling optimum driving force for the acid gas absorption;

2) Computerized structural packing minimizing the absorption liquid malflow;

3) Optimum fiber packing density to minimize the liquid pressure drop and optimize the liquid flow turbulence;

4) Optimized winding patterns to promote the liquid side gas mass transport; and

5) Curved hollow fiber with enhanced gas phase mass transport.

The cartridge was potted by epoxy and sealed with O-rings and housed in a stainless steel pressure vessel. The non-leaking characteristics of membrane modules were determined by pressurizing a water/hexane mixture in the shell side of the module and observing if there was any liquid collection in the tube side. Any liquid collected on the tube side would indicate leakage of the membrane module.

The membrane's intrinsic gas permeation property for $\mathrm{CO}_{2}$ was measured in a flow system shown in Figure 1. The $\mathrm{CO}_{2}$ was fed to the tube side of the module. Flux was measured by a flow meter. The pressure normalized flux, permeance, is:

$$
P=\frac{J}{\Delta p}
$$

where $J$ is the total steady state flux through the membrane and $\Delta p$ is pressure differential between the tube and shell sides. Since the module has a cross-flow design, a log-mean pressure drop $(\Delta p)$ was used to calculate the driving force from the partial pressures

$$
\Delta p=\frac{\left(P_{f, i}-P_{p}\right)-\left(P_{f, o}-P_{p}\right)}{\operatorname{Ln}\left[\left(P_{f, i}-P_{p}\right) /\left(P_{f, o}-P_{p}\right)\right]}
$$

where $P_{f, i}, P_{f, o}$, and $P_{p}$ are the pressures of gas feed inlet, gas feed outlet and the permeated gas, respectively. The pressure in the permeate side $\left(P_{p}\right)$ was typically between 0 and 1.4 psig in our tests. 


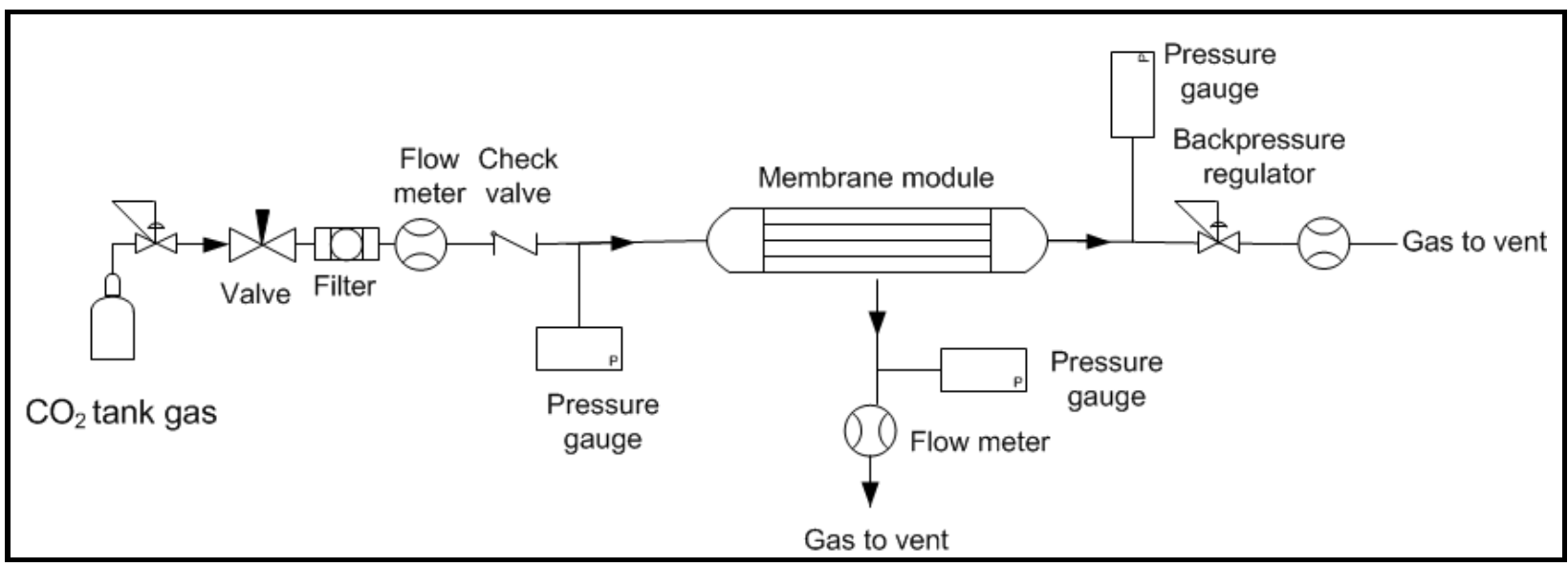

Figure 1. Process diagram for membrane intrinsic permeance measurement.

\subsection{Lab Testing}

The 2-inch diameter membrane modules were mounted in a membrane contactor skid for $\mathrm{CO}_{2}$ capture testing. The skid was designed for $25 \mathrm{~kW}_{\mathrm{e}}$ equivalent $\mathrm{CO}_{2}$ capture $\left(50.6 \mathrm{lb} / \mathrm{hr}\right.$ of $\left.\mathrm{CO}_{2}\right)$. The process flow diagram is shown in Figure 2.

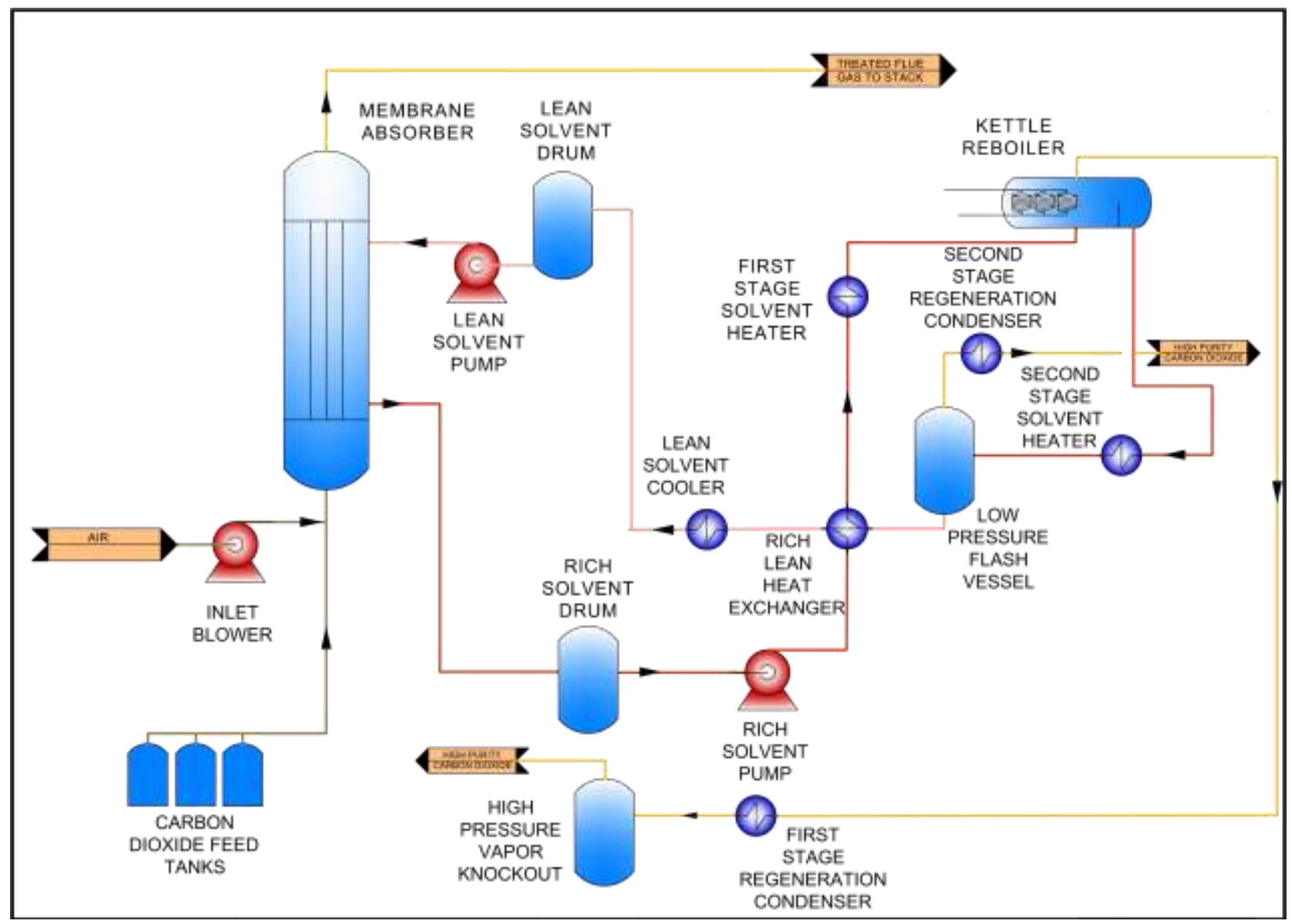

Figure 2. Process flow diagram of the membrane contactor system used in lab testing. Yellow lines are gas and orange lines are liquid 
Compared to packed columns, where a gas side pressure drop is typically about $50 \mathrm{mBar}(0.73$ psi) for $\mathrm{CO}_{2}$ capture, our PEEK membrane contactor process can also operate at close to atmospheric pressure. The only requirement related to pressure of hollow fiber membrane contactor process is that the inlet flue gas pressure must be slightly higher than the ambient pressure in order to ensure uniform flue gas flow through the hollow fibers. In our lab tests, a blower (SPEEDAIRE, Model: SA $3300 \mathrm{~V}$ ) was used to boost room air with a flow rate up to 900 SLPM a discharge pressure up to 6 psig. Carbon dioxide from liquid $\mathrm{CO}_{2}$ tanks was mixed with air to create a "simulated flue gas" and injected into the gas inlet of the absorber. The flow rate of $\mathrm{CO}_{2}$ was controlled by a mass flow controller which can provide up to $600 \mathrm{SLPM}$ of $\mathrm{CO}_{2}$. This range of flow rates allowed us to change the inlet $\mathrm{CO}_{2}$ concentration as needed. The inlet composition of the simulated flue gas was measured by a Horiba PG-350 flue gas analyzer.

The mixed gas was then directed to the tube side of the module (hollow fibers with porous walls), while a lean, $\mathrm{CO}_{2}$ selective solvent was introduced to the shell side of the membrane. Carbon dioxide permeated through the membrane pores and was absorbed in the solvent. Activated methyldiethanolamine (aMDEA) with a piperazine to methyldiethanolamine ratio of 1:4 (wt.\%) was used as solvent. Two concentrations (40 wt.\% and $50 \mathrm{wt} . \%$ amine solution) were tested. The treated gas composition was measured by either by a Qubit S158 $\mathrm{CO}_{2}$ analyzer (QUBIT SYSTEMS S158 IRGA Carbon Dioxide $\left(\mathrm{CO}_{2}\right)$ Analyzer, 0-10\% range) or a Horiba PG-350 flue gas analyzer.

Rich, $\mathrm{CO}_{2}$-laden solvent exited the top of the membrane module. The rich amine pump provided the driving force to circulate the solvent and to maintain the stream as a single, liquid phase until it reached the first heater. A once-through reboiler (Kettle reboiler shown in Figure 2) was used to allow the vaporized $\mathrm{CO}_{2}$ to separate from the rich amine. Vapor exiting the reboiler flowed to a regeneration condenser, where the stream was cooled, and then to a high pressure vapor knockout, where water condensate was separated from the intermediate-pressure $\mathrm{CO}_{2}$. The $\mathrm{CO}_{2}$ vapor stream leaving this knockout (typically with a pressure of 50-72 psig) was depressurized to measure the flow rate and then vented to atmosphere.

"Moderately" rich amine, or mid-rich amine, exiting the once-through reboiler was then sent to the second heater, where the solvent was reheated to break $\mathrm{CO}_{2}$-solvent bonding. The two-phase stream flows to the low-pressure separator, where water and additional $\mathrm{CO}_{2}$ vaporize at this lower pressure. This vapor stream was cooled, and sent to a lower pressure vapor knockout, where water condensate was separated and sent back the lean amine drum. The $\mathrm{CO}_{2}$ vapor stream leaving the 
knockout (typically with a pressure of 3-10 psig) was depressurized to measure the flow rate and then vented to atmosphere.

Upon exiting the low-pressure separator, the hot lean amine was partially cooled through a cross-exchange with the cool, rich amine. This lean solvent was further cooled before being sent to the lean solvent drum. Solvent from the lean solvent drum was pumped to the membrane module for absorption to complete the liquid cycle.

The typical operating conditions for the integrated absorption/desorption lab testing are listed in Table 1. These operating conditions were similar to those typically employed in the field for $\mathrm{CO}_{2}$ capture except the $\mathrm{O}_{2}$ concentration was higher. For comparison to conventional contactors, volumetric mass transfer coefficient $\left(K_{G} A_{v},(s e c)^{-1}\right)$ was used in the current study.

Table 1. Operating conditions for integrated absorption/desorption lab testing.

\begin{tabular}{|c|c|}
\hline Parameter & Condition \\
\hline \multicolumn{2}{|l|}{ Membrane Absorption } \\
\hline Membrane contactor surface area & $11-32 \mathrm{~m}^{2}$ \\
\hline Gas inlet temperature & $18-27^{\circ} \mathrm{C}$ \\
\hline Gas flow rate & $330-775 \mathrm{~L} / \mathrm{min}$ \\
\hline Feed gas composition & $\mathrm{CO}_{2} /$ balance air \\
\hline Feed gas $\mathrm{CO}_{2}$ concentration & 6.4-16.6 (vol.)\% \\
\hline Gas inlet pressure & $3.3-5.9 \mathrm{psig}$ \\
\hline Solvent inlet temperature & $18-40^{\circ} \mathrm{C}$ \\
\hline Solvent flow rate & $2.0-5.5 \mathrm{~L} / \mathrm{min}$ \\
\hline Solvent composition & aMDEA $/ \mathrm{H}_{2} \mathrm{O}(40$ wt. $\%$ or 50 wt. $\%)$ \\
\hline Solvent inlet pressure & $3.1-9.8 \mathrm{psig}$ \\
\hline \multicolumn{2}{|l|}{ Desorption } \\
\hline Solvents & aMDEA $/ \mathrm{H}_{2} \mathrm{O}(40$ wt. $\%$ or 50 wt. $\%)$ \\
\hline Liquid flow rate & $3.40-5.9 \mathrm{~L} / \mathrm{min}$ \\
\hline First stage flash temperature & $119-128^{\circ} \mathrm{C}$ \\
\hline First stage flash pressure & $50-72$ psig \\
\hline Second stage flash temperature & $112-118^{\circ} \mathrm{C}$ \\
\hline Second stage flash pressure & $15-30 \mathrm{psig}$ \\
\hline
\end{tabular}




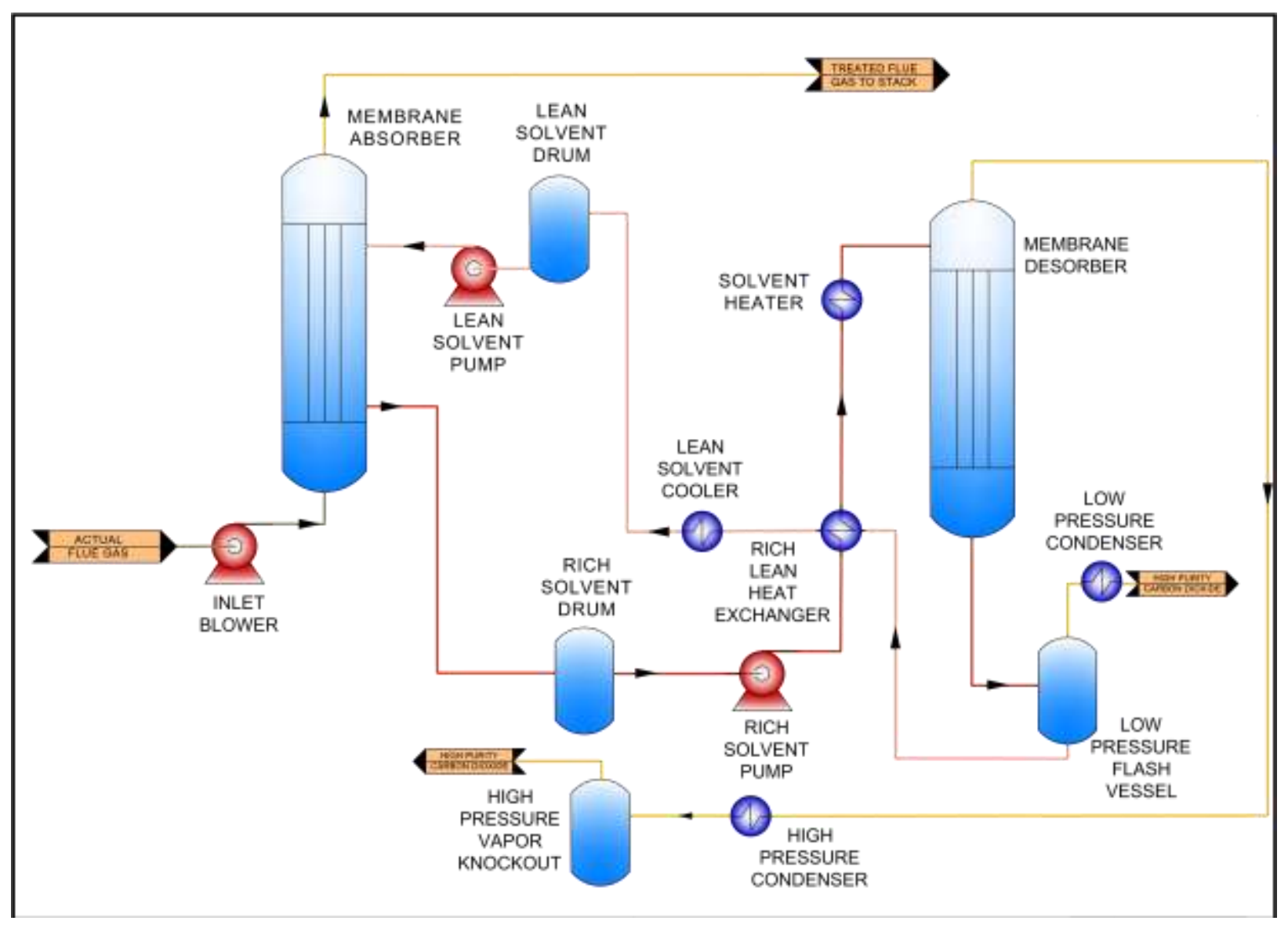

Figure 3. Process flow diagram of the membrane contactor system used in field testing.

\subsection{Field Testing}

The $\mathrm{CO}_{2}$ capture performance of a 4-inch-diameter module $\mathrm{M} 1$ was tested in a coal-fired power plant (Midwest Generation's Will County Station located in Romeoville, IL). The process was identical to the lab testing with the following exceptions:

1) Real flue gas was used instead of simulated flue gas as feed gas; and

2) Membrane desorber was used as the first stage regeneration (Figure 3).

The typical operating conditions for the integrated absorption/desorption testing at the field are listed in Table 2. 
Table 2. Operating conditions for the integrated absorption/desorption testing at the field.

\begin{tabular}{|l|l|}
\hline \multicolumn{1}{|c|}{ Parameter } & \multicolumn{1}{c|}{ Condition } \\
\hline Membrane Absorption & $11 \mathrm{~m}^{2}$ \\
\hline Membrane contactor surface area & $120-220 \mathrm{SLPM}$ \\
\hline Flue gas flow rate & $14-23^{\circ} \mathrm{C}$ \\
\hline Flue gas inlet temperature & Listed in "Results and Discussion" section \\
\hline Flue gas composition & $3.8-5.1 \mathrm{psig}$ \\
\hline Flue gas inlet pressure & $1-2 \mathrm{~L} / \mathrm{min}$ \\
\hline Solvent flow rate & $16-21{ }^{\circ} \mathrm{C}$ \\
\hline Solvent inlet temperature & $\mathrm{aMDEA} / \mathrm{H}_{2} \mathrm{O}(40 \mathrm{wt} . \%)$ \\
\hline Solvent composition & $2.4-4.0 \mathrm{psig}$ \\
\hline Solvent inlet pressure & \\
\hline \multicolumn{2}{|l|}{} \\
\hline Membrane Desorption & $\mathrm{aMDEA} / \mathrm{H}_{2} \mathrm{O}(40 \mathrm{wt} . \%)$ \\
\hline Solvents & $1-2 \mathrm{~L} / \mathrm{min}$ \\
\hline Liquid flow rate & $104-122^{\circ} \mathrm{C}$ \\
\hline Solvent flash vessel temperature & $40-55 \mathrm{psig}$ \\
\hline Solvent flash vessel pressure & $40 \mathrm{psig}$ \\
\hline $\begin{array}{l}\text { Solvent pressure drop across the } \\
\text { membrane }\end{array}$ & \\
\hline
\end{tabular}

Regeneration was carried out using a trans-membrane pressure drop method reported previously [20]. The rich solvent was feed to the shell side of the contactor. The $\mathrm{CO}_{2}$ stripping rate as high as $2.8 \mathrm{~kg} / \mathrm{m}^{2} / \mathrm{h}$ was observed for a $8 \mathrm{wt} . \% \mathrm{CO}_{2}$-loaded aMEDA solvent at $104{ }^{\circ} \mathrm{C}$ and with a trans-membrane pressure drop of 60 psi.

\section{Results and Discussion}

\subsection{Membrane and Module Properties}

Post-combustion $\mathrm{CO}_{2}$ capture process conditions require development of hollow fibers with large diameter bore dimensions to minimize the feed side pressure drop; even a small increase in the gas side pressure drop can introduce a significant energy penalty on the entire power plant. The PEEK fiber dimensions manufactured in the current study were $0.44-0.72 \mathrm{~mm}$ outside diameter and 0.22-0.54 $\mathrm{mm}$ inside diameter (Table 3). 
Table 3. Fiber dimensions.

\begin{tabular}{|c|c|c|c|}
\hline Module & Cartridge diameter (inch/cm) & Fiber OD $(\mathrm{mm})$ & Fiber ID $(\mathrm{mm})$ \\
\hline M1 & $4 / 10$ & 0.44 & 0.22 \\
\hline M2 & $5 / 13$ & 0.72 & 0.54 \\
\hline M3 & $8 / 20$ & 0.71 & 0.54 \\
\hline M4 & $8 / 20$ & 0.59 & 0.37 \\
\hline
\end{tabular}

Membrane cartridge design and construction have significant impacts on the overall gas mass transport coefficient by minimizing liquid side resistance, maximizing the driving force and increasing the liquid side mass transport coefficient. Important design features of a cartridge include the regularity of fibers (poly-dispersity and spatial arrangements of fibers), packing density and the relative flow directions such as parallel, concurrently, counter-currently, and cross-flows of the two phases. In the current study, as shown in Figure 4, the fiber membrane cartridges were firstly scaled up from 2 inch diameter and 16 inch long to 4 inch diameter and 58 inch long (a factor of 90 increase in membrane area), and then from 4 inch to 8 inch diameter (another factor of 3 increase in membrane area).

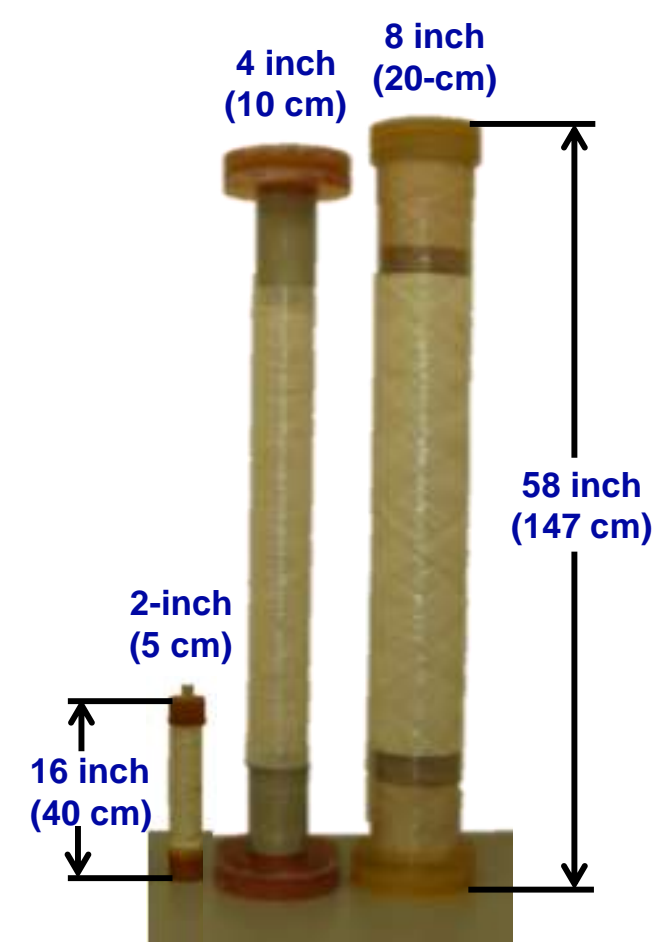

Figure 4. Scale-up of membrane cartridge.

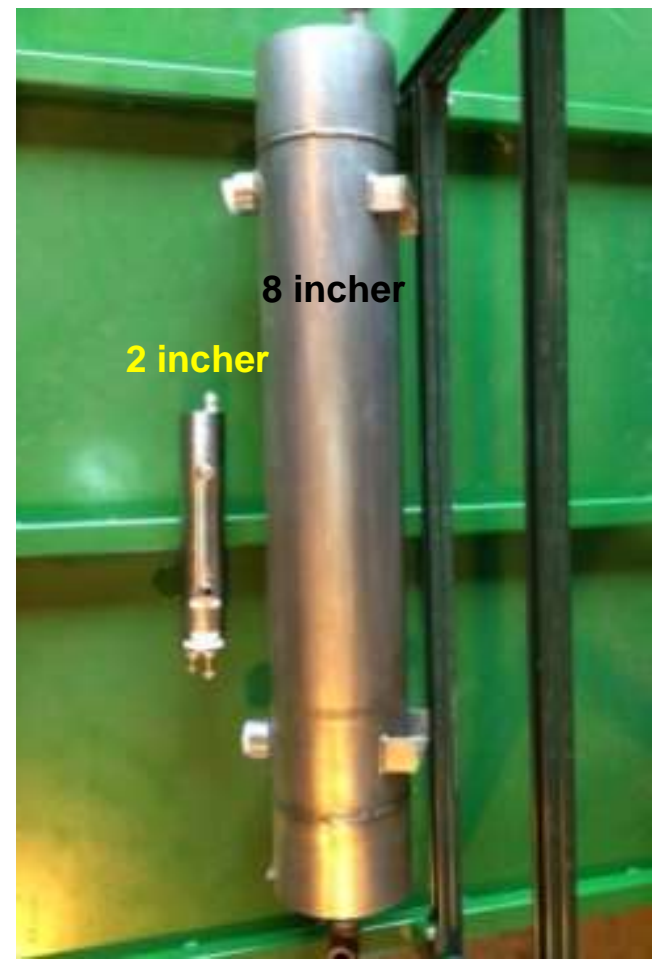

Figure 5. Pressure shells for 2-inch-diameter and 8inch-diameter cartridges. 
The membrane cartridge was sealed with O-rings and housed in a stainless steel pressure vessel (Figure 5). In the current study, the hollow fiber membrane module was designed to operate with liquid on the shell side and gas flow on the bore side. Four-port counter-current flow design, enabling optimum driving force for $\mathrm{CO}_{2}$ absorption.

High membrane intrinsic $\mathrm{CO}_{2}$ permeance is important in attaining high $\mathrm{CO}_{2}$ capture rates in membrane contactor mode. By modifying and optimizing membrane preparation procedures and module construction conditions, membrane intrinsic $\mathrm{CO}_{2}$ permeances as high as 2,000-2,670 GPU (1 GPU $\left.=10^{-6} \mathrm{~cm}^{3}(\mathrm{STP}) /\left(\mathrm{cm}^{2} \cdot \mathrm{s} \cdot \mathrm{cmHg}\right)\right)$ were achieved as shown in Table 4 . Table 4 also lists effective area and specific area of bundle for each of the modules fabricated.

Table 4. Intrinsic permeances for $\mathrm{CO}_{2}$ through 4- to 8-inch-diameter modules.

\begin{tabular}{|c|c|c|c|c|c|}
\hline Module & $\begin{array}{c}\text { Cartridge diameter } \\
\text { (inch/cm) }\end{array}$ & $\begin{array}{c}\text { Membrane } \\
\text { effective inside } \\
\text { area }\left(\mathrm{m}^{2}\right)\end{array}$ & $\begin{array}{c}\text { Bundle } \\
\text { porosity }(\%)\end{array}$ & $\begin{array}{c}\text { Specific area } \\
\text { of bundle } \\
\left(\mathrm{m}^{2} / \mathrm{m}^{3}\right)\end{array}$ & $\begin{array}{c}\text { Module intrinsic } \\
\mathrm{CO}_{2} \text { permeance } \\
\left(\mathrm{GPU}^{*}\right)\end{array}$ \\
\hline M1 & $4 / 10$ & 10.9 & 64.9 & 1,300 & 2,000 \\
\hline M2 & $5 / 13$ & 12.5 & 71.1 & 1,030 & - \\
\hline M3 & $8 / 20$ & 37.6 & 59.4 & 1,560 & 2,670 \\
\hline M4 & $8 / 20$ & 31.8 & 63.5 & 2,620 & 2,150 \\
\hline
\end{tabular}

$*: 1 \mathrm{GPU}=10^{-6} \mathrm{~cm}^{3}(\mathrm{STP}) /\left(\mathrm{cm}^{2} \cdot \mathrm{s} \cdot \mathrm{cmHg}\right)$.

\subsection{Four-inch-diameter Module $\mathrm{CO}_{2}$ Capture Performance}

The $\mathrm{CO}_{2}$ capture performance of the 4-inch-diameter module M1 was tested in a coal-fired power plant (Midwest Generation's Will County Station located in Romeoville, IL). The compositions of the flue gas upstream of the membrane absorber and treated gas downstream of the membrane absorber are shown in Table 5. The $\mathrm{CO}_{2}$ removal rate and flux were 93.2\% and 0.17 $\mathrm{kg} /\left(\mathrm{m}^{2} \cdot \mathrm{h}\right)$, respectively. Note that the local mass transfer coefficient changes along the membrane axial direction because the solvent loading gradually increases. Thus, the average mass transfer coefficient was obtained. The average volumetric mass transfer coefficient for $\mathrm{CO}_{2}$ was $1.2(\mathrm{sec})^{-1}$, which was over one order of magnitude greater than those of conventional contactors with packed columns $\left(0.0007-0.075(\mathrm{sec})^{-1}\right)$ [15]. The $\mathrm{NO}_{\mathrm{x}}$ concentration was $61.1 \mathrm{ppm}$ in the feed and 24.1 ppm in the treated flue gas, respectively. Our previous study indicated that the $\mathrm{CO}_{2}$ capture performance was not affected by flue gas contaminants, including $\mathrm{O}_{2}, \mathrm{NO}_{2}$, and $\mathrm{SO}_{2}$, with the aMDEA solvent in the PEEK membrane contactor process [17] for the duration of the test. 
Table 5. Compositions for the feed flue gas and the treated gas.

\begin{tabular}{|c|c|c|}
\hline \multirow{2}{*}{ Component } & \multicolumn{2}{|c|}{ Composition } \\
\cline { 2 - 3 } & Feed flue gas & Treated flue gas \\
\hline $\mathrm{CO}_{2}$ & $9.06 \mathrm{vol} \%$ & $0.71 \mathrm{vol} \%$ \\
\hline $\mathrm{NO}_{\mathrm{x}}$ & $61.1 \mathrm{ppmv}$ & $24.1 \mathrm{ppmv}$ \\
\hline $\mathrm{SO}_{2}$ & $4.0 \mathrm{ppmv}$ & $4.0 \mathrm{ppmv}$ \\
\hline $\mathrm{CO}$ & $6.0 \mathrm{ppmv}$ & $10.6 \mathrm{ppmv}$ \\
\hline $\mathrm{O}_{2}$ & 11.98 vol.\% & 16.02 vol.\% \\
\hline Balance & $\mathrm{N}_{2}$, water vapor and trace \\
& elements & $\begin{array}{c}\mathrm{N}_{2}, \text { water vapor and trace } \\
\text { elements }\end{array}$ \\
\hline
\end{tabular}

The overall volumetric mass transfer coefficient obtained for the 4-inch-diameter module M1 $\left(1.2(\mathrm{sec})^{-1}\right)$ was lower than that obtained previous for a 2 -inch-diameter module $\left(1.7(\mathrm{sec})^{-1}\right)$ in the laboratory testing [17]. The overall resistance in membrane contactors comes from three parts: in the gas phase, in the membrane, and in the liquid phase. In the following section, each of these factors is analyzed to determine which resistance is responsible for the difference in mass transfer coefficients between the 2-inch-diameter and the 4-inch-diameter modules.

The resistance in the gas phase is typically very small compared to other two [21]. Also, gas velocity and residence time in the fibers of the 4-inch-diameter modules tested in the field were greater than those of the 2-inch modules tested in the lab (Table 6), which would lead to a slightly lower transport resistance in the gas phase. However, we obtained a lower mass transfer coefficient for the four incher, indicating the resistance in the gas phase was not the major factor that caused the difference in mass transfer coefficients between the two incher and the four incher.

Table 6. Gas velocities and residence times in 2-inch and 4-inch module.

\begin{tabular}{|l|c|c|}
\hline \multicolumn{1}{|c|}{ Module } & $\begin{array}{c}\text { Gas velocity in } \\
\text { fiber }(\mathrm{m} / \mathrm{s})\end{array}$ & $\begin{array}{c}\text { Gas residence time in fiber } \\
(\mathrm{s})\end{array}$ \\
\hline 2-inch-diameter module [17] & 3.3 & 0.12 \\
\hline $\begin{array}{l}\text { 4-inch-diameter module M1 } \\
\text { (current study) }\end{array}$ & 4.8 & 0.32 \\
\hline
\end{tabular}

The resistance in the membrane phase is a function of membrane structure. The 4-inchdiameter module M1 had a membrane intrinsic $\mathrm{CO}_{2}$ permeance of 2,000 GPU (Table 4), whereas the 2-inch-diameter module only had a membrane intrinsic $\mathrm{CO}_{2}$ permeance of 1,000 GPU [17]. In contrast, the mass transfer coefficient obtained for the 4-inch-diameter module was $29 \%$ lower than that for the 2-inch-diameter module, indicating the difference in mass transfer coefficients between 
the 2-inch-diameter and the 4-inch-diameter modules was not due to the resistance in the membrane phase.

The resistance in the liquid phase is a function of contactor module design, i.e. flow dynamics, and solvent characteristics. Table 7 shows that the liquid velocity in the 4-inch module was only $40 \%$ of the 2 -inch module. Lower liquid velocity means less turbulence, which may cause a higher resistance in the liquid phase.

Table 7. Liquid flow rates and velocities in 2-inch-diameter and 4-inch-diameter modules.

\begin{tabular}{|l|c|c|}
\hline \multicolumn{1}{|c|}{ Module } & $\begin{array}{c}\text { Liquid flow rate } \\
(\mathrm{L} / \mathrm{min})\end{array}$ & $\begin{array}{c}\text { Liquid velocity in } \\
\text { module }(\mathrm{m} / \mathrm{s})\end{array}$ \\
\hline 2-inch-diameter module [17] & 0.5 & 0.0097 \\
\hline $\begin{array}{l}\text { 4-inch-diameter module M1 } \\
\text { (current study) }\end{array}$ & 1.0 & 0.0039 \\
\hline
\end{tabular}

Based on the analysis above, the lower mass transfer coefficient for the 4-inch-diameter module was likely due to the higher resistance in the liquid phase. Besides mass transfer coefficient, $\mathrm{CO}_{2}$ loading of the rich solvent is another scaling parameter that should be considered in a practical operation; the higher $\mathrm{CO}_{2}$ loading of the rich solvent, the lower amount of liquid to be heated, and thus reducing the energy demand for regeneration. Table 8 shows that the L/G ratio for the 4 -inchdiameter module was only $10 \%$ of that for the 2 -inch-diameter module. The rich solvent $\mathrm{CO}_{2}$ loading was much higher in the four incher relative to the two incher. The rich solvent $\mathrm{CO}_{2}$ loading of 5.2 wt.\% in the fielding testing with 4-inch-diameter module was comparable to those of the packed columns in conventional absorption process.

Table 8. Flow conditions and rich solvent $\mathrm{CO}_{2}$ loadings in 2-inch-diameter and 4-inch-diameter modules.

\begin{tabular}{|c|c|c|c|c|c|c|}
\hline Module & $\begin{array}{c}\text { Flue gas } \\
\text { flow rate } \\
\text { (L/min) }\end{array}$ & $\begin{array}{c}\text { Gas side } \\
\text { pressure } \\
\text { drop (psi) }\end{array}$ & $\begin{array}{c}\text { Liquid } \\
\text { flow rate } \\
\text { (L/min) }\end{array}$ & $\begin{array}{c}\text { Liquid side } \\
\text { pressure } \\
\text { drop (psi) }\end{array}$ & $\begin{array}{c}\text { L/G ratio } \\
\text { (L/L) }\end{array}$ & $\begin{array}{c}\text { Rich solvent } \\
\mathrm{CO}_{2} \text { loading } \\
\text { (wt.\%) }\end{array}$ \\
\hline $\begin{array}{c}\text { 2-inch-diameter } \\
\text { module [17] }\end{array}$ & 12 & 1.6 & 0.5 & 1.3 & 0.042 & $0.6 \%$ \\
\hline $\begin{array}{c}\text { 4-inch-diameter } \\
\text { module M1 } \\
\text { (current study) }\end{array}$ & 245 & 4.1 & 1.0 & 2.5 & 0.0041 & $5.2 \%$ \\
\hline
\end{tabular}

\section{3. $\mathrm{CO}_{2}$ Capture Performance in Membrane Contactor for an 8-inch-diameter Module}

After the field tests with the 4-inch-diameter module, the PEEK hollow fiber membrane modules were further scaled up to eight inch diameter. The 8-inch-diameter module M4 was tested 
in membrane absorption for $\mathrm{CO}_{2}$ capture using $40 \mathrm{wt} . \%$ and $50 \mathrm{wt} . \%$ aMDEA solvents. Carbon dioxide (from liquid $\mathrm{CO}_{2}$ tanks) mixed with air was used as "simulated flue gas" in such lab tests.

A two-stage stripping process was used to regenerate the solvent. This regeneration process is particularly suited for regenerating $\mathrm{CO}_{2}$ laden rich amine solvent in the post-combustion $\mathrm{CO}_{2}$ capture process. $\mathrm{CO}_{2}$ is collected at elevated pressure (around $50 \mathrm{psig}$ ) thus lowering the overall power requirement for $\mathrm{CO}_{2}$ compression while regenerating the solvent for recirculating to the absorber side of the $\mathrm{CO}_{2}$ capture process.

Table 9 shows that greater than $90 \% \mathrm{CO}_{2}$ removal rates were achieved with $\mathrm{CO}_{2}$ mass transfer coefficients of $1.5(\mathrm{sec})^{-1}$ for both solvents.

Table 9. Carbon dioxide capture performance for an 8-inch-diameter module.

\begin{tabular}{|c|c|c|}
\hline Solvent & $\begin{array}{c}\mathrm{CO}_{2} \\
\text { removal rate }\end{array}$ & $\begin{array}{c}\text { Volumetric mass transfer } \\
\text { coefficient for } \mathrm{CO}_{2}\left((\mathrm{sec})^{-1}\right)\end{array}$ \\
\hline 40 wt.\% aMDEA & $91.4 \%$ & 1.5 \\
\hline 50 wt.\% aMDEA & $91.3 \%$ & 1.5 \\
\hline
\end{tabular}

The liquid velocity in the 8-inch-diameter module M4 $(0.0047 \mathrm{~m} / \mathrm{s})$ was slightly higher than that of the 4-inch-diameter module M1 $(0.0039 \mathrm{~m} / \mathrm{s})$. So, the liquid side resistance was expected to be lower for the 8-inch-diameter as compared to the 4-inch-diametr module. Also, the 8-inchdiameter module M4 had a higher $\mathrm{CO}_{2}$ intrinsic permeance (2,150 GPU) than the 4-inch-diameter module M1 (2,000 GPU), and thus M4 should have a lower membrane transport resistance. For a same solvent of 40 wt.\% aMDEA, higher mass transfer coefficient for $\mathrm{CO}_{2}$ was observed for the 8inch diameter membrane (relative to the four incher) because of the lower resistances in the membrane and in the liquid phase.

Table 9 also shows that the $40 \mathrm{wt} . \%$ and $50 \mathrm{wt} . \%$ aMDEA solvents had the identical $\mathrm{CO}_{2}$ capture performance at steady state. Simulation by ProTreat ${ }^{\circledR}$ indicates that the $\mathrm{CO}_{2}$ saturation concentrations are $13.7 \mathrm{wt} . \%$ for the $40 \mathrm{wt} . \%$ aMDEA and $16.6 \mathrm{wt} . \%$ for the $50 \mathrm{wt} . \%$ aMDEA. Since the $50 \mathrm{wt} \%$ aMDEA solvent has a potential to operate at higher $\mathrm{CO}_{2}$ loading for the rich solvent, it was selected for further studies.

In the absence of intramodule cooling in the membrane absorber, the rich amine accepted the $\mathrm{CO}_{2}$ heat of absorption such that the rich amine exiting the modules had a higher temperature than the lean amine entering the module. The theoretical temperature increase is calculated here to compare with the measured temperature.

The heat generated by the reaction was calculated using the following equation: 


$$
Q_{r x n}=\dot{m} C_{p} \Delta T
$$

Where

$Q_{r x n}=$ heat of reaction

$\dot{\mathrm{m}}=$ mass flow rate of solvent

$\mathrm{C}_{\mathrm{p}}=$ specific heat capacity

$\Delta \mathrm{T}=$ temperature change

In this case, the heat of reaction is calculated based on Equation 4:

$$
Q_{r x n}=\dot{m} \Delta H
$$

Where

$\Delta H=$ enthalpy of reaction

$\dot{\mathrm{m}}=$ flow rate of $\mathrm{CO}_{2}$ reacted

The parameters and values used in the calculation are listed in Table 10.

Table 10. Parameters and values used in the calculation of heat generated by reaction.

\begin{tabular}{|c|c|c|c|}
\hline Parameter & Value & Unit & Source \\
\hline $\begin{array}{c}\text { Cp for } 50 \mathrm{wt} \% \\
\text { aMDEA }\end{array}$ & 3.29 & $\mathrm{~kJ} / \mathrm{kg}-\mathrm{K}$ & HYSYS simulation \\
\hline m (solvent) & 3.91 & $\mathrm{~L} / \mathrm{min}$ & Experimental data \\
\hline Solvent density & 1.05 & $\mathrm{~kg} / \mathrm{L}$ & HYSYS simulation \\
\hline$\dot{\mathrm{m}}\left(\mathrm{CO}_{2}\right.$ reacted $)$ & 2.7 & $\mathrm{~mol} / \mathrm{min}$ & Experimental data \\
\hline$\Delta H$ & 76 & $\mathrm{~kJ} / \mathrm{mol}$ & $\begin{array}{l}\text { Svensson et al. [22] modified for our } \\
\mathrm{CO}_{2} \text { loading }\end{array}$ \\
\hline
\end{tabular}

Assumptions are:

- $\mathrm{C}_{\mathrm{p}}$ is constant/independent of temperature; and

- No heat losses (they are calculated next, this is the baseline case).

Based on the above values, the $\Delta T$ calculated was $15.2^{\circ} \mathrm{C}$. The heat generation was $2.9 \mathrm{~kW}$. In our system, the inlet temperature to the absorber is $20^{\circ} \mathrm{C}$, so the outlet temperature would be $35.2^{\circ} \mathrm{C}$.

Heat loss from the absorber to the surroundings are calculated using Equation 6, accounting for conductive heat losses. Convective heat losses are assumed to be negligible, since the air is stagnant. Radiative heat loss was calculated but was determined to be negligible ( $<0.1 \%$ of conductive losses) so is not discussed here. 


$$
q=\bar{h} A\left(T_{s}-T_{\infty}\right)
$$

Where

Where

$$
\begin{gathered}
\bar{h}=\frac{k}{D} \bar{N} u_{D} \\
\bar{N} u_{D}=\left(0.60+\frac{0.387 R a_{D}^{1 / 6}}{\left[1+(0.559 / \mathrm{Pr})^{9 / 6}\right]^{8 / 27}}\right)^{2} \\
R a_{D}=\frac{g \beta\left(T_{s}-T_{\infty}\right) D^{3}}{v \alpha} \\
\operatorname{Pr}=\frac{v}{\alpha}
\end{gathered}
$$

$$
\begin{aligned}
& A=\text { surface area of absorber } \\
& \mathrm{h}=\text { heat transfer coefficient } \\
& \mathrm{D}=\text { diameter of absorber } \\
& \mathrm{k}=\text { heat transfer coefficien } \mathrm{t} \\
& \mathrm{g}=\text { gravitatio nal constant } \\
& \beta=\text { thermal expansion coefficien } \mathrm{t} \\
& v=\text { kinematic viscosity } \\
& \alpha=\text { thermal diffusivit } \mathrm{y} \\
& \mathrm{T}_{\mathrm{s}}=\text { surface temperature of absorber } \\
& \mathrm{T}_{\infty}=\text { ambient te mperature }
\end{aligned}
$$

The parameters and values used in the calculation are listed in Table 11.

Table 11. Parameters and values used in heat loss calculation.

\begin{tabular}{|c|r|l|l|}
\hline Parameter & Value & Unit & Source \\
\hline $\mathrm{k}$ (air) & 0.0243 & $\mathrm{~W} / \mathrm{m} \cdot \mathrm{K}$ & Incropera et al. [23] \\
\hline $\mathrm{T}_{\mathrm{s}}$ & 21 & ${ }^{\circ} \mathrm{C}$ & Measured \\
\hline $\mathrm{T}_{\mathrm{inf}}$ & 4 & ${ }^{\circ} \mathrm{C}$ & Measured \\
\hline $\mathrm{D}$ & 21 & $\mathrm{~cm}$ & From manufacturer \\
\hline $\mathrm{g}$ & 9.8 & $\mathrm{~m} / \mathrm{s}^{2}$ & \\
\hline$\beta$ & 0.00361 & $\mathrm{~K}^{-1}$ & Calculated (from ambient temp) \\
\hline$v$ & $1.37 \mathrm{E}-05$ & $\mathrm{~m}^{2} / \mathrm{s}$ & Incropera et al. [23] \\
\hline$\alpha$ & $1.92 \mathrm{E}-05$ & $\mathrm{~m}^{2} / \mathrm{s}$ & Incropera et al. [23] \\
\hline
\end{tabular}


This calculation gives a heat loss of $60.5 \mathrm{~W}$, which is $2.1 \%$ of the total heat generated. This would decrease the delta $\mathrm{T}$ by $0.94{ }^{\circ} \mathrm{C}$, to give a delta $\mathrm{T}$ of $14.3{ }^{\circ} \mathrm{C}$. The final outlet temperature would then be $34.3{ }^{\circ} \mathrm{C}$. The measured outlet temperature was $29.2{ }^{\circ} \mathrm{C}$.

Zaidiza et al. [24] recently reported an adiabatic modelling of $\mathrm{CO}_{2}$ capture by amine solvents using membrane contactors. They compared the modelling results to those from an isothermal model and investigated the influence of heat release on contactor performance. Similar modelling was conducted in our study. A separate $\mathrm{CO}_{2}$ capture experiment was run and relative humidities of the gas inlet and outlet were monitored. Because dry carbon dioxide (from liquid $\mathrm{CO}_{2}$ tanks) mixed with air was used as simulated flue gas, the relative humidity was between $49.4 \%$ and $52.0 \%$ (Table 12). The outlet of the gas was saturated with water (relative humidity $=100 \%$ ). This is because the liquid side had a higher temperature than the gas side (Table 12), and thus the water vapor pressure was higher in the liquid side, which provided a driving force for the permeation of water vapor from the liquid side to the gas side. Therefore, the measured lower temperature (relative to the theoretical temperature calculated above, i.e. $34.3^{\circ} \mathrm{C}$ ) of the liquid outlet was due to the phase change of water from liquid to vapor.

Table 12. Temperatures and relative humidities for a separate $\mathrm{CO}_{2}$ capture test.

\begin{tabular}{|c|c|c|c|c|c|c|}
\hline \multirow{2}{*}{$\begin{array}{c}\text { Sampling } \\
\text { number }\end{array}$} & \multicolumn{2}{|c|}{ Gas inlet } & \multicolumn{2}{|c|}{ Gas outlet } & \multirow{2}{*}{$\begin{array}{l}\text { Liquid inlet } \\
\text { temperature } \\
\left({ }^{\circ} \mathrm{C}\right)\end{array}$} & \multirow{2}{*}{$\begin{array}{c}\text { Liquid inlet } \\
\text { temperature } \\
\left({ }^{\circ} \mathrm{C}\right)\end{array}$} \\
\hline & $\begin{array}{c}\text { Temperature } \\
\left({ }^{\circ} \mathrm{C}\right)\end{array}$ & $\begin{array}{c}\text { Relative } \\
\text { humidity }(\%)\end{array}$ & $\begin{array}{c}\text { Temperature } \\
\left({ }^{\circ} \mathrm{C}\right)\end{array}$ & $\begin{array}{c}\text { Relative } \\
\text { humidity }(\%)\end{array}$ & & \\
\hline 1 & 28.8 & 52.0 & 28.8 & 100 & 30.4 & 36.0 \\
\hline 2 & 29.2 & 49.4 & 28.9 & 100 & 30.6 & 36.1 \\
\hline
\end{tabular}

Liquid water was collected in the knockout vessel located in the downstream of the membrane absorber, indicating condensation is a potential issue. In the field, the real flue gas is saturated with water vapor. To avoid the condensation issue, the liquid temperature needs to be controlled lower than the flue gas temperature or the flue gas needs to be pretreated to decrease the humidity.

\subsection{Effects of Operation Parameters}

Operation parameters, such as flue gas feed pressure, solvent flow velocity, solvent temperature and $\mathrm{CO}_{2}$ feed concentration in the flue gas, were investigated using the 8-inch-diameter module M4 in conjunction with the $50 \mathrm{wt} \%$ aMDEA solvent. Carbon dioxide mixed with air was used as simulated flue gas. A two-stage stripping process was used to regenerate the solvent. During 
these tests, the gas side pressure drops were between 1.6 and 2.7 psi, whereas the liquid side pressure drops were between 1.3 and 4.1 psi.

\subsubsection{Flue Gas Feed Pressure}

The $\mathrm{CO}_{2}$ capture flux increased with increasing feed pressure of the simulated flue gas (Figure 6) because the gradient of $\mathrm{CO}_{2}$ partial pressures between the gas side and the liquid side increased. As a result, the $\mathrm{CO}_{2}$ removal rate increased from $85.7 \%$ to $93.5 \%$ as feed pressure increased from 2.6 to 5.9 psig.

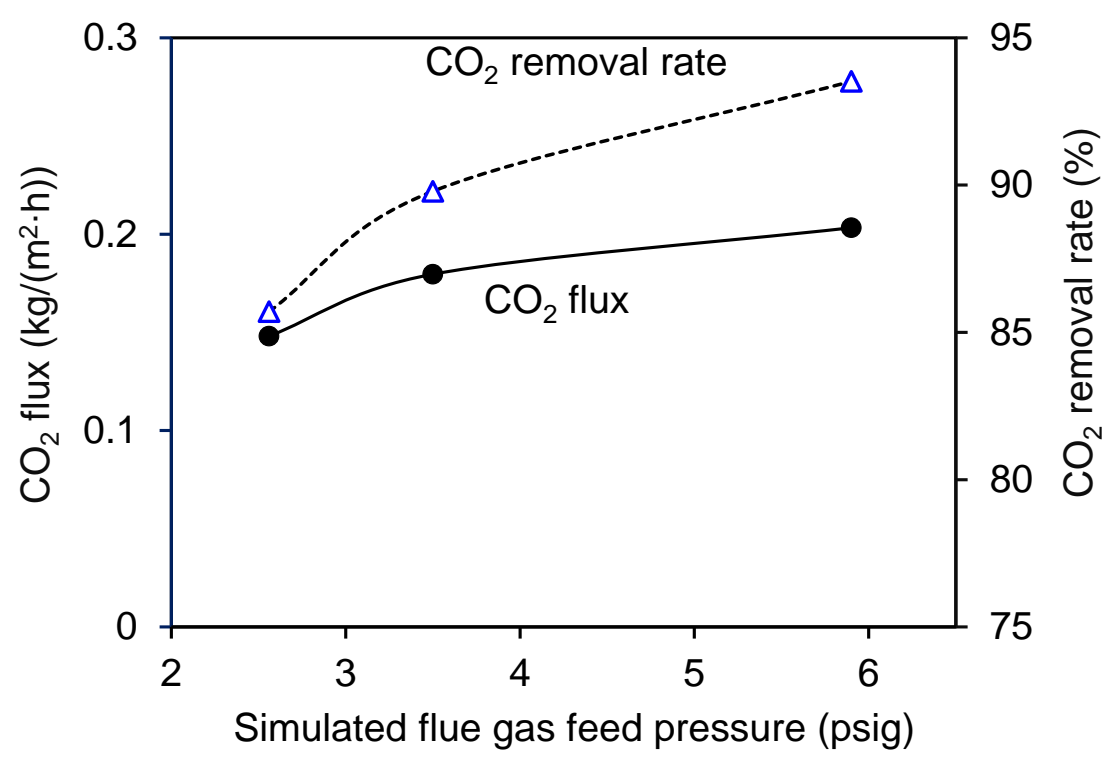

Figure 6. $\mathrm{CO}_{2}$ flux and removal rate of a simulated flue gas at $23{ }^{\circ} \mathrm{C}$ as a function of gas feed pressure. Gas side: $14 \% \mathrm{CO}_{2}$ /balance air, and air flow rate of 340 SLPM; liquid side: 6.9 psig inlet pressure, $21{ }^{\circ} \mathrm{C}$ inlet temperature, and $4 \mathrm{~L} / \mathrm{min}$ flow rate.

\subsubsection{Solvent Flow Velocity}

Figure 7 shows that the $\mathrm{CO}_{2}$ flux increase with increasing solvent flow velocity. This is because the increase in solvent flow velocity increases turbulence for mass transport, and thus decreases the liquid side resistance based on a modeling study by Wang et al. [25]. Due to the increase in $\mathrm{CO}_{2}$ flux, the $\mathrm{CO}_{2}$ removal rate increased from $86.3 \%$ to $91.1 \%$. 


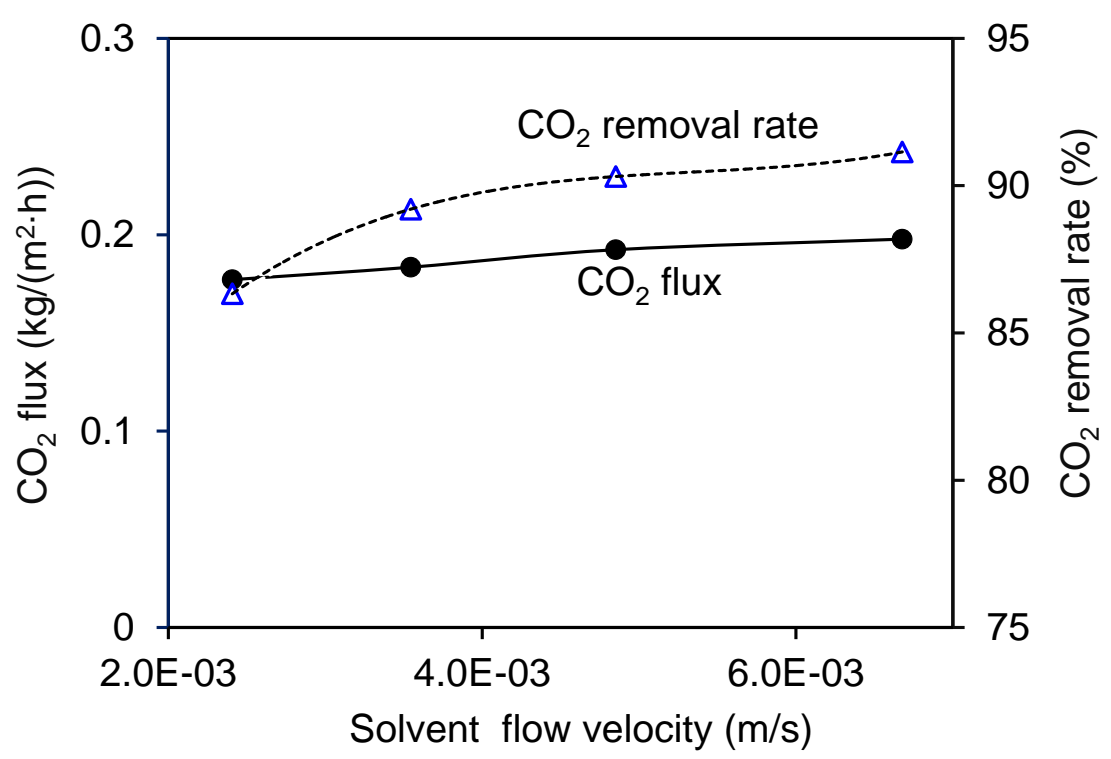

Figure 7. $\mathrm{CO}_{2}$ flux and removal rate of a simulated flue gas at $22{ }^{\circ} \mathrm{C}$ as a function of solvent flow velocity. Gas side: $14 \% \mathrm{CO}_{2}$ /balance air, 3.4 psig pressure and air flow rate of 340 SLPM; liquid side: 5.0-8.8 psig inlet pressure, $22{ }^{\circ} \mathrm{C}$ inlet temperature, and 2-5.5 L/min flow rate.

\subsubsection{Solvent Temperature}

As shown in Figure 8, the $\mathrm{CO}_{2}$ flux increased with increasing solvent temperature. This is attributed to two reasons: 1) the increase in reaction rate, and 2) the decrease in liquid side resistance since the solvent viscosity decreased from 12.8 to $7.4 \mathrm{cP}$ as solvent temperature increased from $22{ }^{\circ} \mathrm{C}$ to $40{ }^{\circ} \mathrm{C}$ per HYSYS simulation. As a result, the $\mathrm{CO}_{2}$ removal rate increased with increasing solvent temperature.

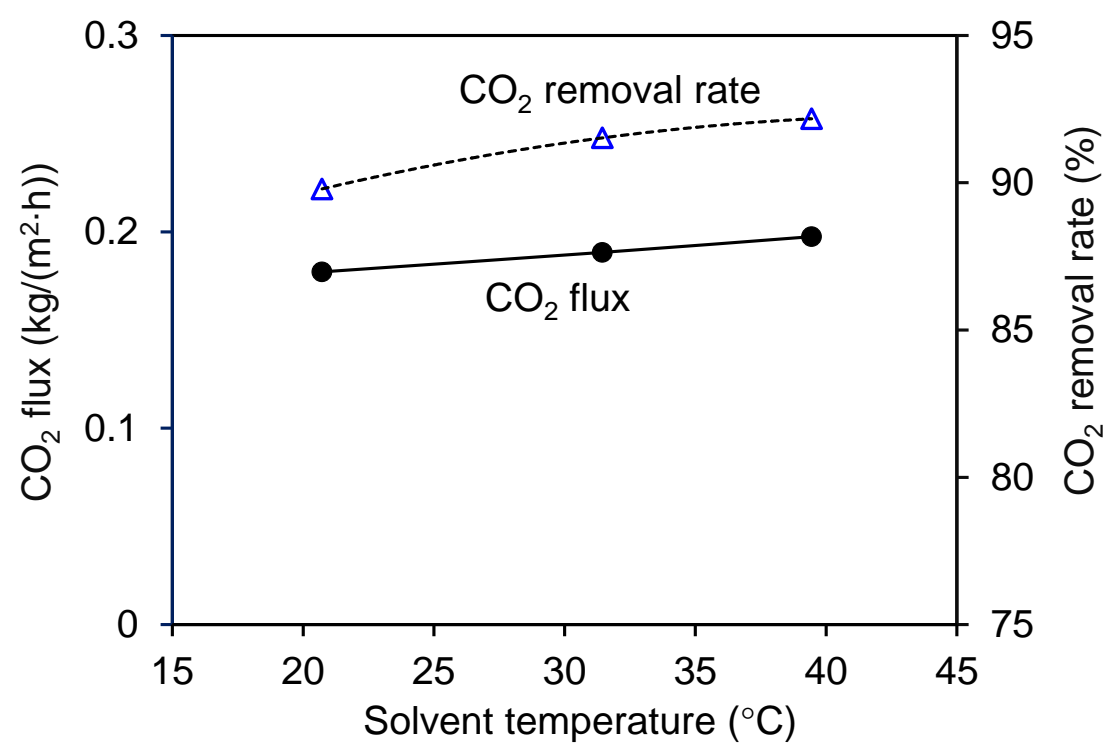

Figure 8. $\mathrm{CO}_{2}$ flux and removal rate of a simulated flue gas at $22{ }^{\circ} \mathrm{C}$ as a function of solvent temperature. Gas side: $14 \% \mathrm{CO}_{2}$ /balance air, 3.6 psig and air flow rate fixed at 340 SLPM; liquid side: 6.1-6.9 psig inlet pressure, and $4.0 \mathrm{~L} / \mathrm{min}$ flow rate. 


\subsubsection{Carbon Dioxide Feed Concentration}

When the $\mathrm{CO}_{2}$ feed concentration in the flue gas is decreased at $23{ }^{\circ} \mathrm{C}$, the $\mathrm{CO}_{2}$ flux decreased, as shown in Figure 9, because the driving force decreased due to the decrease in $\mathrm{CO}_{2}$ partial pressure. The $\mathrm{CO}_{2}$ removal rate (Figure 9), however, increased with decreasing $\mathrm{CO}_{2}$ feed concentration. For a 6.4 vol. \% $\mathrm{CO}_{2}$ feed, the $\mathrm{CO}_{2}$ removal rate was $93.4 \%$ and the treated gas had a $\mathrm{CO}_{2}$ concentration as low as 0.45 vol. \%.

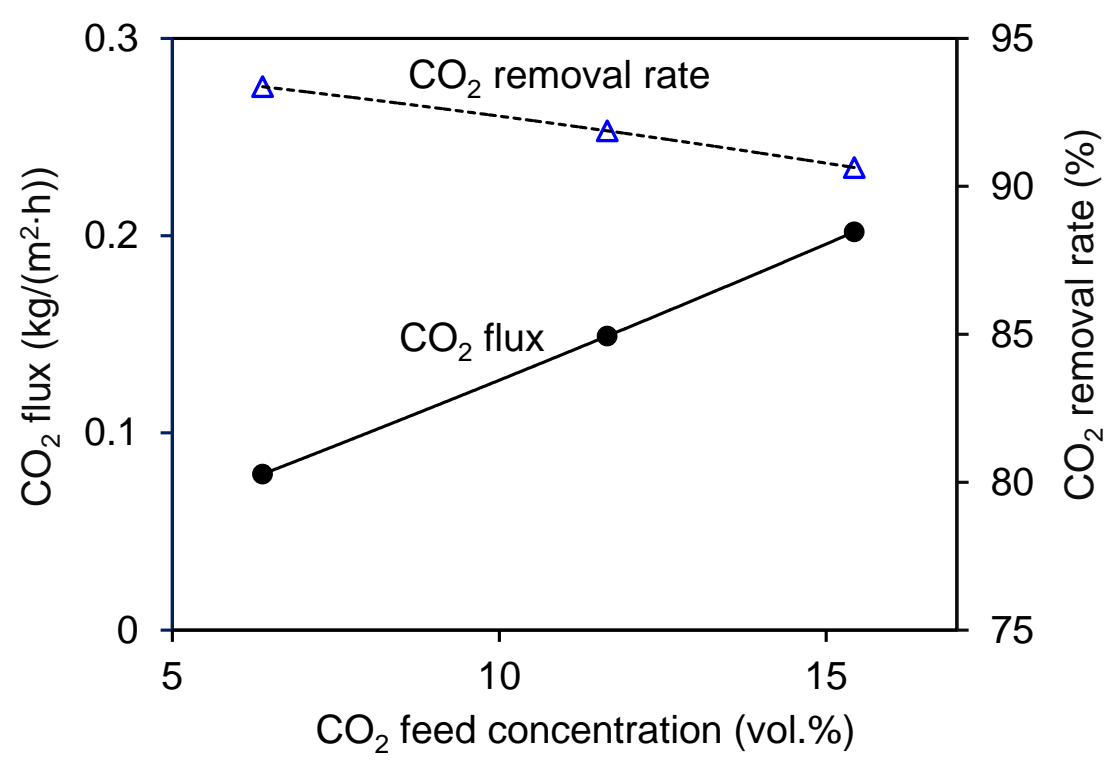

Figure 9. $\mathrm{CO}_{2}$ flux and removal rate at $23{ }^{\circ} \mathrm{C}$ as a function of $\mathrm{CO}_{2}$ feed concentration. Gas side: 3.4 psig inlet pressure, and air flow rate fixed at 340 SLPM; liquid side: 7.0 psig inlet pressure, $22{ }^{\circ} \mathrm{C}$ inlet temperature, and $4 \mathrm{~L} / \mathrm{min}$ flow rate.

In a membrane contractor, due to the chemical interaction of $\mathrm{CO}_{2}$ with the absorption solvent, the permeate side partial pressure of $\mathrm{CO}_{2}$ is essentially close to zero. Therefore, driving force always exists for the transport of $\mathrm{CO}_{2}$ from the gas side to the liquid side. This overcomes the pressure ratio problem encountered by the conventional gas separation membrane configurations. The results shown in Figure 9 indicted that our PEEK hollow fiber membrane contactor process can also be effectively used in $\mathrm{CO}_{2}$ capture from lower $\mathrm{CO}_{2}$ concentration flue gases, such as natural-gas-fired flue gases.

In our previously study [17], PEEK membrane contactor stability was investigated by continuously performing $\mathrm{CO}_{2}$ capture through a two-inch-diameter module with aMDEA solvent for 120 hours. Good mechanical stability and stable permeation properties of the module were observed. The stability of the 8-inch-diameter module will be investigated by a continuous, steady-state operation for a minimum of two months in the field at the National Carbon Capture Center. 


\section{Summary}

- PEEK hollow fiber membrane modules were scaled up from 2 inch diameter and 16 inch length to 4 inch diameter and 58 inch length (a factor of 90 increase in membrane area) for $\mathrm{CO}_{2}$ capture from flue gases using membrane contactor process

- Field test of a 4-inch-diameter module with aMDEA solvent demonstrated a $93.2 \% \mathrm{CO}_{2}$ removal for a flue gas containing 9.06 vol. $\% \mathrm{CO}_{2}$. The mass transfer coefficient in the absorption step was $1.2(\mathrm{sec})^{-1}$, which is over an order of magnitude greater than that of conventional column contactors.

- $\quad$ PEEK membrane module was further scaled up from 4 inch to 8 inch diameter (a factor 3 increase in membrane area). Single-gas permeation measurements indicated that 8-inch modules had an intrinsic $\mathrm{CO}_{2}$ permeance as high as 2,150-2,670 GPU.

- One 8-inch-diameter module was tested in membrane contactor mode for $\mathrm{CO}_{2}$ capture using a simulated flue gas. Carbon dioxide removal rate of $91.3 \%$ was achieved with a mass transfer coefficient of $1.5(\mathrm{sec})^{-1}$.

- Parametric tests indicated $\mathrm{CO}_{2}$ flux and capture rate increased with increasing feed pressure, solvent flow velocity and solvent temperature. PEEK hollow fiber membrane contactor is effective in capturing $\mathrm{CO}_{2}$ from low $\mathrm{CO}_{2}$-concentration feeds, making it high potential for natural gas flue gas $\mathrm{CO}_{2}$ capture.

\section{Acknowledgments}

We gratefully acknowledge support by the US Department of Energy (Contract Numbers DE-FE-0004787 and DE-FE-0012829) and Illinois Clean Coal Institute (ICCI). We thank DOE/NETL Project Manager, José Figueroa, for his assistance and many valuable discussions. We also thank Dennis Leppin for his help in obtaining property data for the aMDEA solvent using ProTreat.

\section{References}

[1] Annual Energy Outlook 2014 with Projections to 2040, Report \# DOE/EIA-0383(2014), April 2014.

[2] DOE NETL, Funding Opportunity Number: DE-FOA-0000785. 
[3] T. Guenther, Power Plant $\mathrm{CO}_{2}$ Capture Overview, LRGCC, March 2008.

[4] M. Ramezan, et al., Carbon Dioxide Capture from Existing Coal-Fired Power Plants, Final Report, DOE/NETL-401/110907, Nov. 2007.

[5] “Updated Costs (June 2011 Basis) for Selected Bituminous Baseline Cases.” August 2012. DOE/NETL-341/082312.

[6] E. Favre, Carbon dioxide recovery from post-combustion processes: Can gas permeation membranes compete with absorption? J. Membr. Sci. 294 (2007) 50-59.

[7] T. C. Merkel, H. Q. Lin, X. T. Wei, R. Baker, Power plant post-combustion carbon dioxide capture: An opportunity for membranes. Journal of Membrane Science, 359 (2010) 126-139.

[8] Y. Yampolskii, et al. Materials Science of Membranes for Gas and Vapor Separation, John Wiley and Sons, 2006.

[9] R. W. Baker, Membrane Technology and Applications, $2^{\text {nd }}$ ed., John Wiley \& Sons Ltd., Chichester, England, 2004, p. 544.

[10] S. Khaisri, D. deMontigny, P. Tontiwachwuthikul, R. Jiraratananon, Comparing membrane resistance and absorption performance of three different membranes in a gas absorption membrane contactor, Sep. Purif. Technol. 65 (2009) 290-297.

[11] D. deMontigny, P. Tontiwachwuthikul, A. Chakma, Using polypropylene and polytetrafluoroethylene membranes in a membrane contactor for $\mathrm{CO}_{2}$ absorption, J. Membr. Sci. 277 (2006) 99-107.

[12] N. Nishikawa, M. Ishibashi, H. Ohta, N. Akutsu, H. Matsumoto, T. Kamata, H. Kitamura, $\mathrm{CO}_{2}$ removal by hollow fiber gas-liquid contactor, Energy Convers. Manage. 36 (1995) 415-418.

[13] D. deMontigny, P. Tontiwachwuthikul, A. Chakma, Comparing the absorption performance of packed columns and membrane contactors, Ind. Eng. Chem. Res. 44 (2005) 5726-5732.

[14] J.L. Li, B.H. Chen, Review of $\mathrm{CO}_{2}$ absorption using chemical solvents in hollow fiber membrane contactors, Sep. Purif. Technol. 41 (2005) 109-122.

[15] B.W. Reed, et al., Chapter 10: Membrane Contactors, in: Membrane Separations Technology: Principles and Applications, R.D. Noble and S.A. Stern, eds., Elsevier Science B.V., 1995, p. 478.

[16] R. P. Lively, M. Dose, L. Xu, J.R. Johnson, K. Zhang, J. Vaughn, M. E. Lydon, J. A. Thompson, J. S. Lee, L. Liu, Z. Hu, M. Realff, W. J. Koros, A High-Flux Polyimide As a Contender for $\mathrm{CO}_{2}$ Recovery From Flue Gas, 2012 North American Membrane Society Meeting, June 9-13, 2012, New Orleans, LA, USA. 
[17] S. Li, D. Rocha, S.J. Zhou, H.S. Meyer, B. Bikson and Y. Ding, Post-combustion $\mathrm{CO}_{2}$ capture using super-hydrophobic, polyether ether ketone, hollow fiber membrane contactors, J. Membr. Sci., (2013) 79-86.

[18] Y. Ding, B. Bikson, Preparation and characterization of semi-crystalline poly(ether ether ketone) hollow fiber membranes, J. Membr. Sci. 357 (2010) 192-198.

[19] Y. Yuan, Y. Ding, Functionalized porous poly(aryl ether ketone) materials and their use, US Patent 7,176,273, Feb 13, 2007.

[20] S. James Zhou, Shiguang Li, Howard Meyer, Yong Ding and Ben Bikson, "Hybrid Membrane/Absorption Process for Post-combustion $\mathrm{CO}_{2}$ Capture," DOE NETL CO2 Capture Technology Meeting, July 8-11, 2013, Pittsburgh, PA, USA.

[21] P.T. Nguyena, E. Lasseuguette, Y. Medina-Gonzalez, J.C. Remigy, D. Roizarda, E. Favrea, A dense membrane contactor for intensified $\mathrm{CO}_{2}$ gas/liquid absorption in post-combustion capture, J. Membr. Sci. 377 (2011) 261- 272.

[22] H. Svensson, C. Hulteberg, H. T. Karlsson, Heat of absorption of $\mathrm{CO}_{2}$ in aqueous solutions of $\mathrm{N}$-methyldiethanolamine and piperazine, International Journal of Greenhouse Gas Control, 17 (2013) 89-98.

[23] Incropera et al. "Fundamentals of Heat and Mass Transfer", Wiley, Hoboken NJ, 2002.

[24] D. A. Zaidiza, B. Belaissaoui, S. Rode, T. Neveux, C. Makhloufi, C. Castel, D. Roizard, E. Favre, Adiabatic modelling of $\mathrm{CO}_{2}$ capture by amine solvents using membrane contactors, J. Membr. Sci. 493 (2015) 106-119.

[25] R. Wang, D.F. Li, D.T. Liang, Modeling of $\mathrm{CO}_{2}$ capture by three typical amine solutions in hollow fiber membrane contactors, Chemical Engineering and Processing 43 (2004) 849-856. 